\title{
Innovative development of Russian enterprises
}

\author{
Maria Mechikova ${ }^{1, *}$, Nataliya Kovaleva $^{2}$, and Olga Vorontsova $^{3}$ \\ ${ }^{1}$ TPI DSTU Branch, Economics and management Department, 347904, Taganrog, Russia \\ ${ }^{2}$ DSTU, Finance and credit Department, 344000, Rostov-on-Don, Russia \\ ${ }^{3}$ RSUE, Innovation management and entrepreneurship Department, 344002, Rostov-on-Don, Russia
}

\begin{abstract}
This study is devoted to the study of industrial innovation in Russia, the analysis of the main indicators of innovation activity, the identification of positive and negative trends in the development of domestic innovation, as well as methods of state support for innovation in Russia.
\end{abstract}

Currently, the leadership of our country is fully aware of the need to transition Russia, and, therefore, all industrial enterprises to an innovative path of development, they are implementing a number of practical measures to implement this course.

But, despite all the measures taken, not all industrial enterprises have so far been active in matters of innovative development. The relevance of the topic of innovative development of industrial enterprises is due to: the scientific objectives of expanding the theoretical ideas about improving the mechanisms of management of innovative activity of enterprises; the practical tasks of creating more effective means and methods of management, the introduction of which should contribute to the formation of the resource component of innovation. One of the first to explore the role of technical innovation in society can be considered a Russian economist N. D. Kondratiev. Through the study of concepts such as" innovation "(invention) and" innovation " (innovation introduced into practice), it revealed the existence of a gap between the moment of the emergence of a technical invention and its implementation, and also showed how the widespread use of significant inventions is gradually evolving into an industrial revolution. As an economic category, the term "innovation" was introduced into scientific circulation by the Austrian economist J. Schumpeter. In his work " Theory of economic development "he first considered the issues of" new combinations " of changes in development and described the innovation process. The term "innovation "was interpreted by him in the widest sense — as change for the purpose of introduction and use of new types of consumer goods, new production, vehicles, the markets and forms of the organization in the industry, considering thus that" the main function of innovative activity is the function of change management [5]. The efficiency of innovative development of the organization is determined on the basis of the ratio of the effect and its costs (Fig . 1). Efficiency-the relative value measured in fractions of a unit or in percent and characterizing result of the made expenses. Efficiency criterionmaximization of effect (profit) at the set costs or minimization of costs (production costs) to achieve a given effect.

\footnotetext{
${ }^{*}$ Corresponding author: mashanovi@yandex.ru
} 
Innovative development is a very complex process. It must be precisely and strictly planned and designed. For this purpose it is necessary to understand correctly what is "innovative development" [1].

Despite the presence of a large number of scientific works in the field of innovation management, the concept of innovation development has not received certainty in interpretation. Many researchers, both foreign and domestic, are widely exploring this concept. Questions related to innovative activity and innovative development of enterprises were considered in works of such foreign scientists, as F. Nixon, L. Vojacek, O. Bogachkova, P. T. La Pierre.

A significant contribution to the solution of problems of innovative processes management at the enterprise has also made the Russian scientists: A. A. Kharin, I. L. Kolinski, Trifilova A. A., Bukhanova, S. M., Yu. A. Doroshenko, Y. Maksimov, S. mityakov, A. Mitkova, T. Fedoseeva, V. B. Khalimendik, N. A. Kuzmin, N. A. Silumina.

From the above it can be concluded that there is a fairly wide range of foreign and domestic research in the field of innovation. Nevertheless, the issues of innovation development directly in the industrial sphere are actualized. This research is devoted to the subject and the purpose of which is to study the innovative development of industrial enterprises in Russia.

Research problem:

- to study the features of innovative development of industrial enterprises in Russia;

- to analyze the main indicators of innovation activity;

- identify positive and negative trends in this development;

- formulate a number of proposals.

In today's world, innovation is necessary to meet the demands of society; it is an indicator of the socio - economic development of the country. The developed countries pay close attention to the innovation sphere: they create separate state structures responsible for the development and implementation of innovations, analyze and compare different technologies, make development ratings.

In recent years, innovations in the industry have been widely spread. This sector, which has proved to be quite promising and economically sound, has good financing.

In the industrial sector, innovations are classified as follows:

- product-introduction of a new or improved product, the functions of which, as well as designs, technical performance and additional operations differ from previous product models;

- process-introduction of new or significantly improved production methods (new equipment, new organizational process).

It is important to understand that aesthetic changes (such as new packaging, new color) do not apply to industrial innovations, as they do not affect the content. This also applies to innovations in management: managerial and organizational innovations are not industrial innovations.

In addition to the main types of innovations listed above, the following varieties are distinguished:

- basic - new inventions and discoveries, on the basis of which a fundamentally new equipment is created;

- improving-modernization of equipment, machinery and materials;

- pseudoinverse - this includes changes that can accelerate the process slightly to improve quality, to save material.

All kinds of innovations introduced in the industry are important, each applied for a certain technological process.

Innovative processes in different spheres of activity differ from each other. The form of innovation depends on the producer of innovations, the scope of implementation, importance, economic impact and many other factors.

Innovation in industry has one important feature: for innovation to be successful and profitable, it must be strategic. Strategic innovation means that a new process (product, 
technology, etc.) should not be a one-time process, it is aimed at the future. Of course, often innovative methods are introduced to overcome the crisis, but a competent Manager will always plan tomorrow.

If we compare industrial innovations with business innovations, we will find a very different picture: for business, a very dynamic sphere of activity that requires quick decision-making during the crisis, it is more important to have an instant effect.

In addition, it should be noted that innovations in the industry differ in the duration of the manifestation of the effect. After all, most often these are large-scale labor-intensive processes that give a financial and economic answer about their profitability after a long time. In contrast, it should be recalled that, for example, innovations in the social sphere or in the field of information technology provide a fairly rapid result.

Research and testing is an essential part of industrial innovation. Research is long and financially costly. For example, service innovations (provision of services) often do not require research, and therefore a lot of funding.

In each country, the attitude to innovation, and accordingly, innovation policy has its own characteristics. This is due to historical events, resources of the country, its political and economic aspirations.

In Germany, industrial innovation has sufficient financing, as well as a strategic model. Due to this, all announced and developed innovations are planned and successfully implemented. The emphasis in industrial innovation Germany is doing in the grocery inventions. Strong branches of the country: chemical production, spare parts to vehicles, electronics, optics, mechanical engineering, pharmaceuticals, electric equipment, cars.

Japan is a country legend in the innovative sphere. Japan is famous for its incredible innovations in all spheres. Strangely enough, the shortfall in which Japan was actively engaged in the creation and substitution of products contributed to the rapid and grandiose development of the country. The main industries for Japan are automotive, nuclear power, electronics, and chemical industries.

USA. there is a diverse development of industry, which has territorial divisions. Significant areas of industry in the United States: engineering, including agricultural, aviation and oil industries.

Switzerland also has a planned innovation course, which includes sufficient financial and legal support from the state. The developed sphere is the manufacturing industry.

China's industry is flexible; research and development is the least expensive compared to other countries. The basis for the introduction of innovations in the industry are such areas as household appliances, the textile industry and the automotive industry, which has achieved significant success over the past 5-10 years.[2]

The main indicators of innovation include the following:

1. Innovative activity of organizations

2. The proportion of organizations engaged in certain types of innovation, in total number of organizations engaged in technological innovation

3. Research divisions in the organizations which were carrying out technological innovations

4. Volume of innovative goods, works and services

5. Export volume of innovative goods, works and services

6. Share of innovative goods, works and services in domestic and foreign markets

7. Structure of exports of innovative goods, works and services

8. The rating of results of innovative activities

9. Share of the organizations participating in the technological exchange in the total number of organizations implementing technological innovations

10. Distribution of organizations involved in technological innovation and exchange by country and region

11. Joint projects to carry out research and development organizations engaged in technological innovation

12. Expenditure on technological innovation 
13. Costs of technological innovation by funding source

14. The share of costs for certain types of innovation activity in the total cost of technological innovation.

The peculiarities of innovation in Russia are ambiguous. On the one hand, Russia is not part of the group of innovatively developed countries, it is not an industrial leader (such as Japan, Germany, the United States), on the other hand, technological innovations in Russia demonstrate positive dynamics. The developed advanced production technologies on groups advanced as a whole across the Russian Federation are given in table 1.

The data in the table show that in General, the number of technological innovations in Russia has increased significantly in recent years, however, Russia is lagging behind in the field of innovation from the West.

The main reasons for the underdeveloped of the innovation sphere in Russia:

- the lack of a definite policy and organization in this sphere: there are no programs and plans for implementation and creation of innovations;

- monopoly-a serious brake on progress and innovation.

Innovation-is, first of all, research, study and development of new. In modern conditions, it is almost impossible for Russia to do such work, because research and expenditure on consumables are not sponsored by government agencies.

Of course, there are good prospects for development: such a large and resource-rich country cannot find itself in a situation of absolute stagnation. Industrial innovations in Russia are of a private nature. Small companies are pioneering modernizations. This brings profit to such companies, and at the same time helps the country to improve the level of industrial development.

The Russian government has long recognized the need to develop innovative activities of industrial enterprises. Today there is more than one plan of innovative development of the Russian industry, and some of them are at the stage of implementation. But, unfortunately only a small part of the enterprises showed activity and interest, both to innovative development, and to introduction of innovations on production. Innovation is a vital necessity for each of the enterprises, because its competitiveness depends on the level of innovative development of the enterprise. We must not forget that it is innovative products that help to compete, to be attractive to new consumers and, of course, to make a profit.

Table 1. The developed advanced production technologies on groups of the advanced production technologies in General across the Russian Federation (units) [3]

\begin{tabular}{|l|l|l|l|l|l|l|l|l|l|l|l|l|l|}
\hline & $\mathbf{2 0 0 0}$ & $\mathbf{2 0 0 5}$ & $\mathbf{2 0 0 6}$ & $\mathbf{2 0 0 7}$ & $\mathbf{2 0 0 8}$ & $\mathbf{2 0 0 9}$ & $\mathbf{2 0 1 0}$ & $\mathbf{2 0 1 1}$ & $\mathbf{2 0 1 2}$ & $\mathbf{2 0 1 3}$ & $\mathbf{2 0 1 4}$ & $\mathbf{2 0 1 5}$ & $\mathbf{2 0 1 6}$ \\
\hline $\begin{array}{l}\text { Developed } \\
\text { advanced } \\
\text { production } \\
\text { technologies-total }\end{array}$ & $\mathbf{6 8 8}$ & $\mathbf{6 3 7}$ & $\mathbf{7 3 5}$ & $\mathbf{7 8 0}$ & $\mathbf{7 8 7}$ & $\mathbf{7 8 9}$ & $\mathbf{8 6 4}$ & $\mathbf{1 1 3 8}$ & $\mathbf{1 3 2 3}$ & $\mathbf{1 4 2 9}$ & $\mathbf{1 4 0 9}$ & $\mathbf{1 3 9 8}$ & $\mathbf{1 5 3 4}$ \\
\hline $\begin{array}{l}\text { Design and } \\
\text { engineering }\end{array}$ & 165 & 138 & 148 & 177 & 173 & 196 & 216 & 316 & 305 & 426 & 445 & 359 & 402 \\
\hline $\begin{array}{l}\text { Production, } \\
\text { processing and } \\
\text { Assembly }\end{array}$ & 281 & 291 & 362 & 365 & 369 & 328 & 383 & 405 & 548 & 517 & 506 & 548 & 509 \\
\hline $\begin{array}{l}\text { Automated } \\
\text { transportation }\end{array}$ & 20 & 9 & 13 & 8 & 14 & 21 & 18 & 24 & 23 & 22 & 22 & 12 & 34 \\
\hline materials and parts & 76 & 91 & 97 & 110 & 99 & 102 & 116 & 128 & 121 & 137 & 110 & 117 & 160 \\
\hline $\begin{array}{l}\text { Automated } \\
\text { surveillance } \\
\text { equipment }\end{array}$ & 90 & 57 & 56 & 67 & 68 & 67 & 70 & 154 & 204 & 206 & 202 & 232 & 285 \\
\hline and / or controls & 18 & 21 & 24 & 14 & 23 & 26 & 20 & 51 & 60 & 68 & 65 & 84 & 83 \\
\hline
\end{tabular}


The main trends of innovative development of the industry are given below.

1. The past few years have shown that Russian enterprises are not interested in innovation development and innovation in General. One of the reasons why this problem has arisen is the lack of the need to develop innovations and innovative development for competition in the Russian market. The Russian manufacturer does not need to introduce new technologies to attract new consumers.

2. When creating competitive advantages, innovation is an unimportant factor. Today, Russian enterprises have a high profitability with low level of technological equipment, low level of labor productivity and minimal $\mathrm{R} \& \mathrm{~d}$ costs. Most of the enterprises are on the side of innovation, such companies do not release any new products that do not implement new technologies and does not engage in research and development. Only some enterprises use and apply already existing technologies.

3. The ever-decreasing level of expenditure on $\mathrm{R} \& \mathrm{~d}$ in Russian enterprises is that before you make something new you need to make the modernization of production. Often the equipment in the workshops is so outdated that it is impossible to produce a product using new or improved technologies. Of course, re-equipment of workshops, purchase of installation and commissioning of new, modern equipment requires significant investment. But as practice shows, the higher the level of investment, the higher the level of innovative development of the enterprise.

4. Among the many problems of innovative development of industrial enterprises, it is possible to identify the main problems that create the most serious obstacles:

5. Imperfection of legislation and lack of laws regulating the introduction of innovations.

6. Low level of financing of innovative activity of enterprises, due to high volumes of investments, and long payback periods. Only some enterprises have their own funds for the development and implementation of innovations, and the search for external sources is difficult.

7. Resistance to innovation, the main reasons for which are:

8. Fear of staff to the innovations;

9. The desire of investors to recoup already having investments, thereby not to invest in several projects of one enterprise.

10. Lack of qualified personnel ready to effectively manage the development and implementation of innovative processes in the enterprise.

11. According to statistics, today, large and state-owned enterprises are active in innovation. This is due to the fact that these enterprises have sufficient funding, a high level of equipment and staffing. There is an urgent need for the formation and implementation of the system of innovative development of Russian enterprises, stable state support, expressed not only by financing, but also by reducing duties on imported equipment. For more effective implementation and development of innovations it is necessary to create special departments and divisions.

Russia has a state policy to support innovation. The main results of the policy pursued in recent years, the purpose of which is to focus the state on an innovative type of socio economic development, can be identified:

- increasing the number of innovative schools and universities implementing innovative educational programs;

- $\quad$ opening of additional research centers and project laboratories at universities;

- creation of technoparks as a form of cooperation between scientific and technical center, innovative enterprises and business for the production of high-tech products;

- the increase in the number of science cities-research and production complexes, which are a set of organizations engaged in scientific and technological innovation, experimental development, etc. in accordance with the state priorities for the development of science and technology; 
- $\quad$ stablishment of state corporations and foundations (for example, the Russian nano - technology Corporation, the state Corporation Russian technologies, Rosatom, the Fund for the promotion of small-scale enterprises in the scientific and technical sphere (Bortnik Fund), the Russian high-tech development Fund, etc.).

In this regard, aktiviziruyutsya tool venture funding, as investing in highly risky innovation business. Forms of stimulation of venture investment by the state are quite diverse:

- $\quad$ direct provision of capital by the state (direct investments and loans);

- financial benefits (tax benefits, loan guarantees, equity investments guarantees).

Governments often develop and implement their own venture capital Fund-raising programmes to support small innovative enterprises. These programmes mainly provide financial incentives (including a variety of tax incentive schemes), but also include direct investment and government loans. These tools can be applied to venture capital funds (management companies) and/or directly to small and medium-sized businesses.

The programme of development of venture capital, developed at the state level, aims to fill the lack of private capital markets, to Supplement the financing of the private sector and create companies (mainly technical and scientific) favorable conditions for development over a long period. The most successful venture capital programs are funded by governments, but managed by professionals from the private sector, public participation in investment decision-making should be minimal.

Innovation cluster is a geographically separate set of scientific, educational and industrial enterprises, contributing to the activation of innovation and competitiveness of the municipality through the development of its innovative potential. Innovation clusters, according to B. N. Digitool are not limited to the field of research and development of high technology, they include the network of institutions that support industrial innovation enterprises, and universities - media science.[4]

An innovation cluster is most often initiated by regional or local authorities, whose task is to provide a stimulating effect (venture, concessional lending, etc.), which generates successful technological innovation. Municipal innovation clusters have already been formed in a number of Russian cities. In particular, the innovative cluster "New communications and information and communication technology"created in Krasnoyarsk is an example. The number of innovative clusters created both at the regional and municipal levels of clusters is increasing every year in Russia.

For selection of national scientific and technical and innovative priorities, formation of the state scientific and technical programs, development of mechanisms of support of innovative development the corresponding researches which results promote identification and strengthening of technological areas in which effective breakthroughs can be carried out and significant competitive advantages are received are carried out. Significant administrative and financial resources are invested in these studies.

Nevertheless, despite clear prioritization, a large number of normative and strategic documents adopted at different levels of government, the availability of a wide range of tools, the effectiveness of the innovation component of Russia's industrial policy is not large enough. This is due to the lack of coordination between the centre and the regions, and haphazardness in the work of Federal ministries and agencies. The problem is "taken away" by them on the basis of the immediate benefits of each. The lack of coordination in the actions of the center and the regions does not allow to fully use the potential and resources of local authorities, social activity of the population.

In Russia, science, education and industry to a large extent are not consolidated. Even the Federal ministries responsible for the country's innovative development act inconsistently, without proper coordination. There is a gap in the single innovation cyclefrom training for research activities to the introduction of new technologies into production. And this alienation leads to erosion of the competitive potential of each of these areas. 
The effectiveness of solving these problems depends not only on how well the national guidelines for innovative development are chosen, but also on how effective the tools are used for their implementation.

However, the analysis of the situation in the field of innovation shows that the activities of public administration in this area are fragmented, and an effective mechanism for the implementation of industrial policy aimed at modernization of domestic production has not yet been created.

In this regard, it is possible to form a number of proposals to improve industrial policy in the direction of the development of innovation, which will lead to the following:

- improving the effectiveness of long-term forecasting of the development of science and technology through the timely clarification of key areas in the field of innovation, on which it is necessary to concentrate the available resources;

- the need to transform the technical and technological basis of social production at a fundamentally new level, providing an adequate reflection of the diversity of socioeconomic, organizational and institutional conditions for the formation of strategies for effective industrial development of Russia's multi-level economic system;

- creation, taking into account the main priorities of modernization of domestic production, of an effective mechanism for the implementation of industrial policy, involving the active interaction of government and business and the coordination of the interests of the state with the needs of the real sector.

In conclusion, it is possible to draw the following conclusions:

1. Improving the efficiency of social production is an immanent factor in the functioning and self-development of the social system, which is currently largely determined by innovation, information and the presence of the factor of science.

2. The analysis showed the presence of a range of indicators of innovative development, many of which Russia lags behind Western countries.

3. Development of innovations in the Russian industry, shifted towards the development of honey. techniques, pharmacology, energy saving, communications and information technologies should be based on maximizing the innovative potential of individual territories, the formation of innovation clusters, venture financing, priority support for research enterprises, etc.within the framework of the mechanism for the implementation of industrial policy.

\section{References}

1. Schumpeter A., The theory of economic development. Camb.; Mass., 1934.

2. Alpeeva T. A., Prospects of innovative development of enterprises / / Young scientist, 2016, No. 1, P. 289-292. URL https://moluch.ru/archive/105/24940/ (accessed: 24.04.2018).

3. Official website of the Federal state statistics service. http://www.gks.ru/

4. Mechikova M. N. Structural-level approach to the development of the institutional and economic mechanism of industrial policy: author. dis. ... kand. Ekon. sciences'. Rostov-on -Don. (2011) -28 p. 